\title{
Ethics and corporate social responsibility - a strategic approach within the organization
}

\author{
Carmina Simion Simescu Martinho Nunes, University Valahia Targovişte, Romania \\ Alexandra Simion Simescu, University of Philosophy, Bucharest, Romania
}

\begin{abstract}
Today, all organizations in the world should recognize the importance and need to take into account concepts such as: ethical, moral, ethical programs, ethical behavior, social responsibility, equity and also try to implement in their organizational culture. So tackling business ethics and social responsibility is an issue today, not only theoretically but also in that of practice. This article explains how several important dimensions of organizational culture may influence the effectiveness and ethics initiatives in the corporate responsibility shock.
\end{abstract}

\section{Keywords}

Ethics, ethics programs, ethical dilemmas, ethics, global business ethics, ethical behavior, Corporate Social Responsibility

\section{JEL Codes: M 14}

\section{Ethics and morality}

Ethics is one of the main branches of philosophy and can be called the science of moral reality. It tries to elucidate moral problems through cognitive exercise. Ethics can also be understood as a philosophy on morality, good, evil and duty.

Etymologically speaking, the word ,ethics” comes from the Greek words Ethos (Homer) = primordial, country, home, reunion place, natal place, habits, character; Ethike (Aristotle) = the science of knowledge. From "Ethos" derived the word "Ethicos", meaning " from off for moral", used by Greeks when they were discussing about the principles of human behavior. For start, we may consider ethics as being the science of ethos (moral), of good and evil (Socrates, Platon, Cicero), of happiness, virtue (Aristotle), of pleasure (Aristip), of social ideal.

Many specialists think - also Peter Drucker - that there is no difference between day by day ethics and business ethics. An outgoing person, an ambitious one or a liar behaves the same way in the office, as well as he does outside of it, therefore we can not limitate or differentiate clearly this conduct, hence the necessity of business ethics must not be proven.

Thomas W. Dunfee, Business Ethics teacher at Wartin School, Univ. Pennsylvania, considers this practice can be suggested by information confidentiality respect of the employee towards the enterprise, contractor towards the clients, a so-called sensibility to conflicts of interests, detecting them, and if possible avoiding them, respecting the rules by outside businessmen with a professional conscience and prudence, cultivating this professional competences, limiting decisions, loyalty and good faith which aims the equity of our actions, a high sense of responsibility, respecting the rules and the freedom of others in behavior, opinions, respecting the human being.

Few people doubt that the good is the center value of ethics or the fact that practical good means the embodiment of values such as justice, courage, sincerity, friendship, altruism, etc. 
Even though, to answer questions such as: What is good and evil? What is justice or courage? We have to appeal to philosophical investigigations - the only instrument we have to enlighten this essential question for our own destiny.

\section{Ethical theories applied in management}

An ethical theory is a conceptual assemble that explains one way or another moral phenomena and usually finalizes thorough a test. So, it is important to know the main ethical theories to which appeal business ethics books and to suggest the solution to some ethical dilemmas, using this theories. These are the ethics of virtue, utilitarianism and the ethics of duty.

In Aristotle's vision ${ }^{1}$, three things are the object of free will and three must be avoided: good, morals, utility and pleasure and their contrary: bad, useless, unpleasant. The definition which says that virtue is a habitus is not enough, we must show which kind of habitus it is, the virtue aims toward the instrument because it has to do with affects and actions, in which there is an exaggeration, a lack and middle. The virtue is a habitus of choice, which is determined by the mind. But as well shown by Nicolai Hartmann, in Ethics ${ }^{2}$, virtue is not only a way, but also a peak. The virtuous man is not a mediocre man, but a superior one. Ethical virtue is a way, out of two evils, the one of exaggeration and the one of the lack which aims towards the affects and middle actions; this is why giving the right amount of money is not so easy. Whoever wants to find the way must leave behind his contrary, which is why the object and the purpose of the action is very important, because judging by the way we choose goes or evil we have a certain moral trait, but not after by our opinions. The purpose is an object of desire and the means are an object of free will, as we can see that the actions aimed to this means are freely chosen. The ethics of virtue proves to be relevant in many contexts for the analysts of specific business ethics problems. In the way that happiness is the result of a life of trying, likewise solid profit can be obtained only through long-term strategies. From another point of view, in the same way that happiness can be accomplished only through brave, just, honest actions, profit can be accomplished following some criteria: products and services that are needed on the market, satisfaction of the clients, stimulating the employees, stable relations with the contractors and creditors, the acknowledgement of the community, respecting the law, paying state fees and taxes, protecting the environment, etc. Business ethics of Aristotelian inspiration focuses on developing positive traits of economical agents, building a set of values centered on social responsibility and altruism.

In money business, the middle is the ability to give, and the exaggeration and the lack is waste and avarice, because both show the extremes. The waster can give too much and take too little, and the greedy takes too much and gives back too little. In business exists also other traits: willingness as middle, then the tendency to spend money for show, and then soul-tightness as a lack? For example, the specific virtue of a manager assumes competence, authority, flexibility, tact, strength in decision-making, but above all, a good businessman is the one that accomplishes good profit through his inititiatives. But nobody can be just a manager; a full human being implies other qualities than market success. This is the motive why searching profit, as an economical agent, mustn't leave out any other value criteria from the life and activity of a businessman; as a full man, he must build this attitudes and traits meant to give him dignity and happiness.

Good cooperation is the one that guesses everything which is exact for our life goals, whilst good council hits the exact point for a certain business. Hence, the Prisoner's Dilemma emphasizes the fact that everyone could be in a worse situation than it could be in the

\footnotetext{
${ }^{1}$ Aristotel(1998), Etica nicomahică, Editura Ştiințifică şi Enciclopedică, Bucuresti, p. 23

2 Hartman, N (1926), Ethick, Walter de Gruyter Co., Berlin, p. 56
} 
situation of cooperation, meaning that everyone would lose if we were to follow only our own interests.

For the ethical virtue it is important that a human being manifests to certain things feelings of love or hate. These feelings influence all the events in life because they are so full of meaning and decisive for virtue and happiness. The man becomes virtuous after an opinion from nature, another one from custom and the last one through learning. So, business ethics after Aristotle emphasizes the building and the developing positive traits of economical agents, improving a set of values centered on social responsibility, with traditions and values unanimously accepted. Can it be that a return to Aristotle's ethics, where ethical behavior is primordial, in this troubled times could be a good thing?

Utilitarism, iniated by Jeremy Bentham and restructurated in his classic form by John Stuart Mill $^{3}$, has a consecventialism perspective, according to which, a good deed is not defined by the intentions than originate it, nor by the goals followed, but through its effects or consequences. Whilst Aristotle believed that good deeds are those done by good people, defining the character man, the utilitarists claim that a good man is the one that always or almost always does the right thing, trying to give an answer to the question „What is a good deed?" or "When can our deeds be considered good?". Their answer is immediate and apparently simple: moral actions are the ones that through their consequences increase the quantity of good in the world, while the immoral ones increase the quantity of evil. For them, happiness means „obtaining pleasure and avoiding sufferance”, while unhappiness, associated with evil, means lack of pleasure and intensified sufferance.

Bentham and Mill were raising a soar of „social hedonism”, based on the following principle: "the conception that accepts as a fundament of moral Utility or the Greatest Happiness Principle claims that actions are right if they tend to propagate happiness and wrong if they tend to produce unhappiness. Through happiness we understand pleasure and the lack of pain, and through unhappiness pain and the absence of pleasure. We must add that The Greatest Happiness Principle acquires his utilitarism semnification only when it says that the maximum of pleasure is morally right when it comes upon the largest amount of people, not only one.

Assuming that a company with the premises on the outskirts that pollutes the environment over the acknowledged limit is pursuing the selfish goal to maximize its profit in the long run and to distract the community from the main issue (that it pollutes the environment). The company does generous deeds for the stakeholders (employees, clients, local community). Utilitaristic speaking, this generosity is ok as long as a large amount of people receive a certain benefit: employees get bonuses, they take their kids to the company's kindergarten and practice sports on its premises; local community gains money for football team, museums, hospitals; this things offer, if not a certain guarantee of ethical value, at least chances of approaching it. Hence, in Mill's view, to decide and act to the good of the many persons means respecting the rules of behavior that were proven to assure the maximum of satisfaction. Still, this theory applied to business leads to some circumstances in which may appear social injustice, an inequity share of resources, so to some moral restraints.

For Kant ${ }^{4}$, the intention, and not the consequence of the acts matter in establishing its moral values. The autonomy of will is its capacity of not being influenced by affects or feelings. Duty is the center of his theory: any action in order to acquire moral value must be done from duty, relying on a categorical imperative like: , You must...” In order to be moral, the maxima of our action must be necessary and universal, that the person should always be regarded as a purpose and never as a mean. Many authors think that the most influent theory nowadays is the one that continues Kant's moral philosophy, with the question: why should we be moral? If Aristotle said that the only virtue, specific to the man of character, leads to a true deserved happiness - the goal human existence, utilitarianism claimed that the idea of

\footnotetext{
${ }^{3}$ Mill, J. S.(1994) Utilitarismul, trad. rom. Valentin Mureşan, Editura Alternative, Bucureşti, p. 18

${ }^{4}$ Kant, I(1972), Critica rațiunii practice, Editura Ştiinţifică, Bucureşti, p. 39
} 
morality is in everyone's benefit, because decisions and moral acts lead to the maximum happiness of more people. Kant offers another view: the consequences of our acts are lacking any moral value if they are the effects of some accidental gestures or if we make them animated by motives and selfish intentions. For Kant, the intention and not the consequences matter in establishing moral value. The next question is: About what kind of intentions are we talking? We are moral as long as what guides is not the selfish desire, but the desire to act after certain rules or moral rules. In this theory, there is only one categorical imperative, to which Kant finds three different approaches, each one of them stating another aspect of moral condition. The first one: , act only by that maxima that may become universal law". 5 Kant asks us to first establish the principle after which we act - called maxima. Then we take the consistency test to see if our maxima can be followed by everybody. In business, universal imperative is applied in many situations. For example, if in a commercial we deliberately state lies, the principle would be: „Lie to increase your business profit.” Can this become a universal principle? Of course not. If everybody would make cheating commercials, nobody would believe them.

Kant exposes and argues the most profound of his ethical ideas: morality means respecting your own rules, imposed by you, on the conditioned that they are validated by a reason as general universal laws, because by applying them, the humanity in every person is respected. Aware by his innovative idea, Kant said: „,it could be seen that the man was tied to the laws by his duty, but nobody knew he was only obedient to his own legislation and that this legislation is still universal, and that he must act by his own will, that due to its purpose is universal law-giving". So, moral Kantian philosophy is one of the most important moral theories not only for its intrinsic qualities, but also due to its interdisciplinary.

The theories that I have analyzed are not the only ethical constructions that try to elucidate the specifically problems of business ethics. The best approach is the analysis of different ethical problems in all these perspectives, to search the complementarily of these three views as categorical references on which you can found a coherent personal decision, that takes into account concrete aspects of business environment, especially in this time of crisis.

Ethical dilemmas in organization can be expressed as less clear situations, problems that put managers in difficult positions, wanting to take the best decision for the society's performance. „Ethical paradox” can be per submitted to interrogation by the businessman: should he assume responsibility and risks of his economical activity or to remain to the moral, abstract judgment, lacking responsibility? This dilemma responsibility/morality moves the emphasizes towards ethical theories and their application, behavior and ethical programs from „moralist” to responsibility ethics. The interest for an ethical business conduct isn't new, but only now the interest for moral actions in order to maintain competitively is acknowledged.

\section{Social responsibility}

Lately, a new dimension of ethics is growing Romanian market: corporate social responsibility. Do companies operating in debt or have turned up and that responsibility means of manipulation and persuasion? In the classical view, "The only social responsibility in business management is to maximize profits" ${ }^{6}$, but in terms of socio-economic, "social responsibility beyond profit management, including protecting and enhancing the welfare of society as a whole". The most developed and most widely accepted model of corporate social responsibility is quadripartite model originally proposed by Archi Carroll in 1979 and later refined in 2000 in cooperation with Buchholtz.

\footnotetext{
${ }^{5}$ Ibidem

${ }^{6}$ Friedman, M.(1970) The Social Responsibility of Business Is to Increase Its Profits , New York Times, p. 89
} 
$\underline{\text { Studies and Scientific Researches - Economic Edition, no. 15, } 2010}$

Table no.1 Model of corporate social responsibility

\begin{tabular}{|l|l|}
\hline Philanthropic responsibilities & Desired by society \\
\hline Ethical Responsibilities & Expectations of society \\
\hline Legal Responsibilities & Incurred by society \\
\hline Economic Responsibilities & Incurred by society \\
(Source: Carroll, A. B., Buchholtz, A. K.(2000) Business and Society: Ethics and Stakeholder Management, 4th \\
edition, Cincinnati, South- Western College., p. 102)
\end{tabular}

The concept of corporate social responsibility means and responsibility to be a bear to public organizations, but also required companies to comply with legal and ethical standards both in the public and private. Accountability requires tools to ensure compliance with legal and ethical standards, such as codes of conduct and principles, performance indicators and quality management, reporting patterns, guides implementation and manifested in policy and practice responsible office. At the international level have been developed a series of documents that include principles of corporate responsibility practices. Thus, the United Nations Global Compact is a set of principles, which intended to promote global social responsibility and to stress the importance of local networks consisting of NGOs, private companies and governments to solve social problems. He is an international network of national networks; to facilitate dialogue companies, individuals and organizations who share the same ideas and values that have committed to promoting socially responsible corporate citizenship. Another tool is composed of the OECD principles of corporate governance. Under that document, companies must comply with policies established by the countries where they operate. Corporate governance principles were first published in 1999, becoming an international reference in corporate governance. To take account of developments after 1999 , the principles were revised in 2003, of a larger process of regional consultations. The new principles were approved by OECD governments in April 2004. The OECD principles, implementing an effective system of corporate governance should lead to transparency and market efficiency, consistent with the rule of law and to define clearly the distribution of responsibilities between courts on supervision, regulation and application of laws. Tripartite Declaration on Multinational Enterprises and Policy ILO Governing Board initially adopted this statement in 1977 , reviewing it in the 2000 . The document is a directive with non-urgent application in areas such as:

- Employment

- Equal opportunities and treatment

- Safety at work

- Training

- Working and living conditions

Amounts of increasingly tough question on the establishment of mechanisms for implementing the RSE, that building a system to ensure social accountability. In this regard, Amnesty International maintains that the most effective means of ensuring that companies assume legal responsibility would be its national legislation in terms of world economic integration, the international legal framework needs to be echoing the ethical rules of conduct applicable internationally. They may not invent; they are contained in the Universal Declaration of Human Rights. Thus, international law would not come to replace national laws, but would act as a reference point and palliation where national law would be impaired. Given that the social responsibility is the enforcement, to the company unable to dissociate the legislation governing its activities, the legislation under consideration may be structured on various criteria. Romanian legislation is extremely rich in this respect, providing a 
legislative framework appropriate and sufficient covering. At 7-8 of November 2006 first edition held in Bucharest International Conference on Corporate Social Responsibility. Organized under the high patronage of the World Business Council for Sustainable Development and the UN Global Compact is the first event CSR addresses corporate social responsibility in an integrated approach, treating and youth involvement in the concept. There are certainly a number of other questions that can be made and that should be answered. Moreover, the refinement with which such questions are explored is the difference between success and ethical reflection credible. We live today in a hurried world, a world that still seeks its meaning and moral correctness is associated with business success, even if not a sufficient guarantees it. CSR is a rather ambiguous concept of capitalism, which however cannot be completely without the purposes of our report and the ethical dimensions of practice. Best be implemented in a mature market and Romania is unfortunately far to get there.

\section{References}

1. Aristotel(1998), Etica nicomahică , trad. rom. Stella Petecel, Ed. Ştiințifică şi Enciclopedică, Bucureşti.

2. Benedict Spinoza(2000), Etica, Ed. Antet, Bucureşti.

3. Carroll, A. B., Buchholtz, A. K.(2000) Business and Society: Ethics and Stakeholder Management, 4th edition, Cincinnati, South- Western College.

4. Craciun Dan, Vasile Morar, Vasile Macoviciuc(2005) Etica afacerilor, Ed. Paideea, Bucureşti.

5. Drucker, Peter(1992), Administrando para o Futuro São Paulo: Pioneira.

6. Friedman, M.(1970) The Social Responsibility of Business Is to Increase Its Profits, New York Times

7. Hartman, N (1926), Ethick, Walter de Gruyter Co., Berlin, p. 56

8. Immanuel Kant,(1972) Critica rațiunii practice, Ed. Ştiințifică, Bucureşti.

9. Mill, J. S.(1994) Utilitarismul, trad. rom. Valentin Mureşan, Ed. Alternative, Bucureşti.

10. Joao Pinto E Castro(2002) - Comunicação de marketing, Silabo Gestao, Lisabona.

11.M. Kaptein,(1998) Ethics Management. Auditing and Developing the Ethical Content of Organizations, Kluwer Academic Pub.

12. Kotler \& Dubois(2003) - "Marketing Management", Pearson Education France, Paris.

13. D. Menzel(2007), Ethics Management for Public Administrators, Sharpe, London.

14. Popa I, Filip R(1999), Management Internațional, Ed. Economică, Bucureşti.

15. Samuel Mercier(1999), L'etique dans les entreprises, Editions La Decouverte et Syros, Paris.

16. Quinn J. B.(1994) - L'entreprise intelligente. Savoir, service et technologies, Dunod, Paris. 